\title{
The Growth Improvement of Grammatophyllum scriptum (Lindl.) Bl. In Vitro Plantlet using Photoautotrophic Micropropagation System
}

\author{
Aries Bagus Sasongko ${ }^{1}$, Asruwaidah Fatumi ${ }^{1}$, Ari Indrianto ${ }^{1, *}$ \\ ${ }^{1}$ Laboratory of Biotechnology, Faculty of Biology, Universitas Gadjah Mada, \\ Jalan Teknika Selatan, Sekip Utara, Yogyakarta 55281, Indonesia
}

\begin{abstract}
To improve the growth of Grammatophyllum scriptum (Lindl.) Bl. in vitro plantlet, a photoautotrophic micropropagation system (PMS) was developed by growing in vitro plantlet on VW medium with varying concentration of sucrose $(0,5,10$, and $20 \mathrm{~g} / \mathrm{L}$ ) and additional carbon dioxide from the air (bottle covered with cap or filter). The result showed that the leaf length would increase up to $6.5 \mathrm{~cm}$ with PMS and it would keep growing by the adding of $5 \mathrm{~g} / \mathrm{L}$ sucrose. Average number of leaves increased by 6.7 strands with PMS and the addition of sucrose increased the average quantity of leaves up to 7.7 strands. Average number and root length would increase with PMS and would even increase more with $5 \mathrm{~g} / \mathrm{L}$ sucrose addition. PMS with $5 \mathrm{~g} / \mathrm{L}$ sucrose can increase chlorophyll $\mathrm{a}$ and $\mathrm{b}$ concentration. The number of stomata per unit area in PMS was lower than closed culture. This shows that PMS can increase the growth of G. scriptum in vitro plantlet and the growth increase would be effective if it is combined with sucrose addition.
\end{abstract}

Keywords: Plant growth, Grammatophyllym scriptum plantlet, photoautotrophic micropropagation system, in vitro, carbon dioxide

\section{Introduction}

Indonesia is one of the countries in the world with the biggest source of biodiversity of orchids, which is approximately 5000 species (Irawati, 2001). Some species of orchids have been used as ornamental plants because of its high aesthetic value (Yulia and Ruseani, 2008). The tiger orchid Grammatophyllum scriptum (Lindl.) BI. is one of the best orchids with high aesthetic value due to the number of flowers per stack (25-50 flowers); long lasting and vigor, which makes them very good to be an ornamental plant (Hani, 2015).

Propagation of wild orchids like G. scriptum is needed for conservation and cultivation. Natural orchid propagation has a low success rate. According to Hani (2015), the environment has a significant role in propagating orchids naturally in their habitat. The environment comprises moisture,

\section{*Corresponding author:}

Ari Indrianto

Laboratory of Biotechnology, Faculty of Biology, Universitas Gadjah Mada, Jalan Teknika Selatan, Sekip Utara, Yogyakarta 55281, Indonesia

E-mail: ariindri@ugm.ac.id temperature, and light, along with the structure of orchid seeds that impede natural germination. A microscopic-sized orchid seed consists of two parts, which are embryo and testa (seed coat) (Soeryowinoto, 1987). Most of orchid seeds do not have endosperm, so it also impedes the growth and development of the orchid embryo in nature (Hani, 2015).

In vitro culture is one of the main techniques to propagate orchids. With this culture, orchids can be propagated easily and quickly (Rosdiana, 2010). The orchid plantlets will face environmental stress when they are transferred to the ex vitro environment, so it has a higher risk of death. This happens because the structures of the plantlets have thin cuticle layer, imperfect vascular tissue, and reduced stomata function (Torres, 1989). In addition, plantlets in in vitro culture area used to being in heterotrophic condition with a supply of nutrients available in the culture medium, so the adjustment in the autotrophic condition in acclimatization process is going to be difficult. That is why an appropriate in vitro propagation technique is needed so the orchid plantlets will have a higher success rate when doing acclimatization. 
Factors that affect in vitro plant growth are the type and concentration of carbohydrate, mineral nutrient, phytohormones, light, temperature, medium $\mathrm{pH}$, moisture, gas exchange, and contamination. Plantlets as results of in vitro culture have a low capability of photosynthetic rate, so it needs additional sugar to grow. The lack of gas exchange in conventional in vitro culture causes the reduction in oxygen and carbon dioxide and the increase ethylene gas accumulation. This condition will impede the growth process accelerate aging process (Hew and Yong, 2004).

Photoautotrophic micropropagation system (PMS) is a micropropagation method using media without sugar, vitamin, and amino acid, and only with inorganic materials only. This system emphasizes on the $\mathrm{CO}_{2}$ contents, light intensity, and relative moisture. The advantages of this method are to reduce microbial contamination risk and increase plantlets' growth by giving light and high amount of $\mathrm{CO}_{2}$ in the bottle (Xiao and Kozai, 2006). This method can induce photosynthetic process. PMS has been proven to enhance the growth of Cymbidium, Phalaenopsis, and Epidendrum orchids (Teixera da Silva et al., 2005). In order to improve the growth of $G$. scriptum in vitro plantlet, research about the effects of PMS on G. scriptum in vitro plantlets is needed.

\section{Materials and Methods}

\section{Plant material and growth condition}

G. scriptum plantlets aged 12 months and have two leaves were grown in Vacin and Went (VW) medium in accordance with Arditti (2008) with variations of sucrose (0, 5,10 , and $20 \mathrm{~g} / \mathrm{L}$ ) and variations of bottle caps, which were aluminium foil and rubber cap with filter based on certain modified pipe (Table 1). The culture was maintained by giving continuous lighting and room temperature $25^{\circ} \mathrm{C}$ for eight weeks. A preliminary test on the amount of carbon dioxide that got into the culture bottle was done in accordance with Haney et al. (2008).

\section{Chlorophyll concentration test}

Chlorophyll concentration in orchid plantlets was measured at the beginning and the end of the research in accordance with Specht et al. (1975). The plantlet leaves weighing $0.1 \mathrm{~g}$ were crushed in a porcelain mortar and dissolved in $10 \mathrm{~mL}$ of $80 \%$ acetone, then filtered with filter paper. The solution was put into the test tube and covered with aluminum foil and then absorbance was measured using spectrophotometer with the wavelength of $645 \mathrm{~nm}$ and $663 \mathrm{~nm}$. Chlorophyll concentration was calculated using the following Eq. 1 and 2.

Chlorophyll $a=0.0127$ (Abs 663) -0.00269 (Abs 645) (mg/g) Eq.1 Chlorophyll $b=0.0229($ Abs 645) $-0.00468($ Abs 663) $(\mathrm{mg} / \mathrm{g}) \quad$ Eq.2

\section{Measurements of growth parameter}

The leaves that were counted were those that had perfect shape and green in color. All measurements were done once a week for eight weeks.

\section{Anatomic preparation of stomata and leaves Leaves of G. scriptum plantlet from each treatment were taken and polypropylene- based glue was smeared on the abaxial surface as the mold. After it dried, the glue was peeled and observed under a microscope with a magnification of $10 \times 10$, and then the calculation of the number of stomata with leaf area of 4 $\mathrm{mm}^{2}$ was made. The transverse section of the leaves was observed by making new incisions on the third plantlet leaf with a holder in the form of carrot slices to make the incisions easier. The result was put in the beaker glass}

Table 1. Variation of sucrose concentration in VW medium.

\begin{tabular}{lllll}
\hline \multirow{2}{*}{ Treatment } & \multicolumn{3}{c}{ Sucrose concentration in medium $(\mathrm{g} / \mathrm{L})$} \\
\cline { 2 - 5 } & 0 & 5 & 10 & 20 (control) \\
\hline $\begin{array}{l}\text { Capped bottle (control) } \\
\begin{array}{l}\text { PMS treatment bottle } \\
\text { (with certain pipe) }\end{array}\end{array}$ & 3 bottles & 3 bottles & 3 bottles & 3 bottles \\
\hline
\end{tabular}




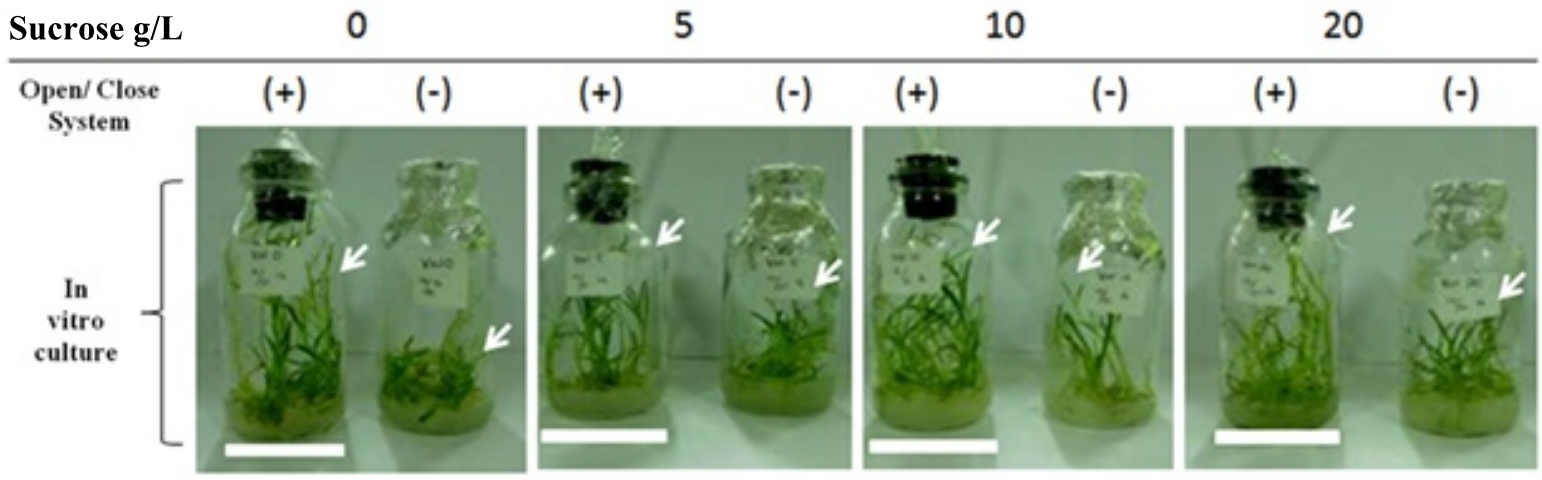

Figure 1. Morphology of G. scriptum plantlets in the open and closed system with various sucrose concentration. Photoautotrophic micropropagation system, which is an open system with a sucrose-less medium. Sign $(+)$ indicates open system $/ \mathrm{CO}_{2}$ addition from the air, and sign (-) indicates closed system/no air exchange. The arrow sign indicates the height of plantlets in in vitro culture. Scale bar $=5 \mathrm{~cm}$.

and observed using a light microscope with magnification of $4 \times 10$. The pictures were taken using Optilab.

\section{Results and Discussion}

This research uses two systems in vitro cultures: closed system and open system. The difference between these two systems lies in the air exchange factor between in vitro culture and ex vitro environment. The difference between these two systems has an impact on the environment of in vitro culture. The closed system has high moisture, low $\mathrm{CO}_{2}$, and ethylene gas accumulation. In contrast, the open system has relatively low moisture, there was more of $\mathrm{CO}_{2}$ and there
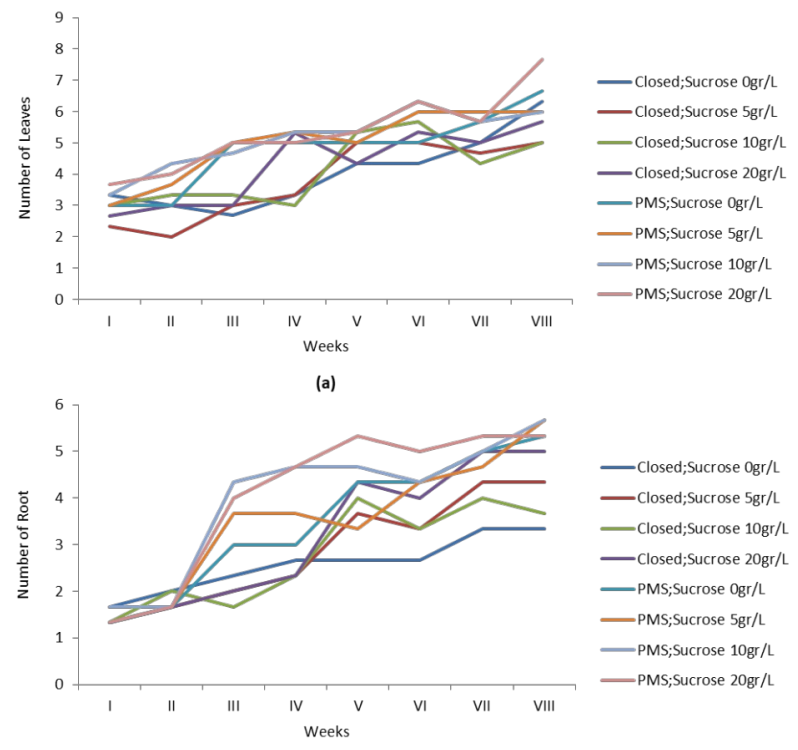

was no accumulation of ethylene.

PMS applies the open in vitro culture system with modification of sucrose-less medium. Plantlets grown using this system will have a better growth rate than that using the closed system. In addition, the survival rate of in vitro plantlet will increase because of its ability to adapt to the ex vitro environment.

This research focuses on the growth of G. scriptum plantlets through in vitro cultivation in closed and open systems both by PMS medium without sucrose and with sucrose. Growth characters observed were the leaf organs and roots, along with chlorophyll content.

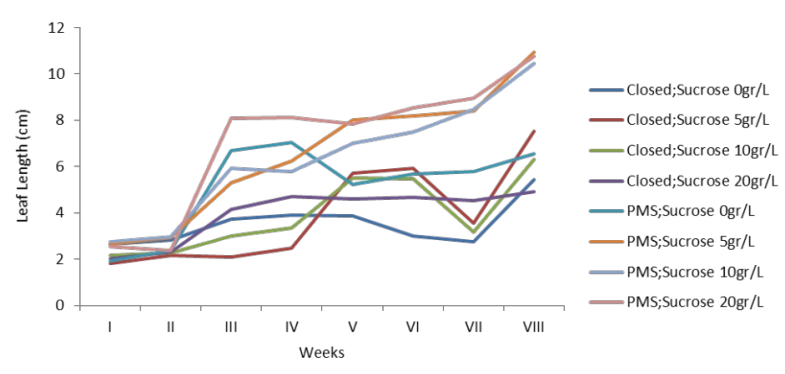

(b)

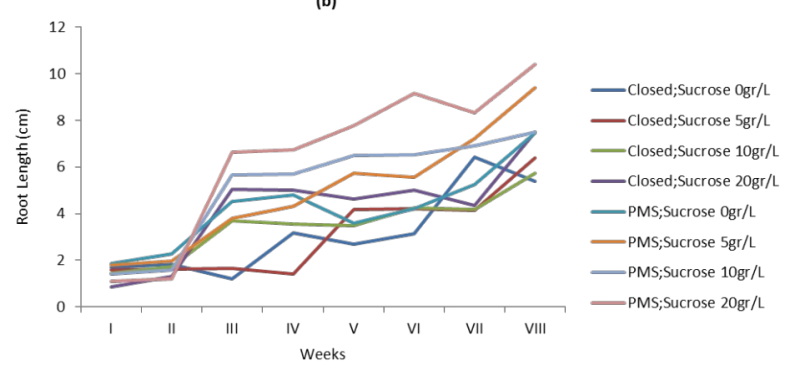

(d)

Figure 2. The growth of leaves and roots organs of G. scriptum plantlets on various treatments: a) number of leaves; b) leaf length; c) number of roots; d) length of root. 


\section{Growth of leaves and root in G. scriptum plantlets}

G. scriptum plantlets grown on medium without sucrose and addition of $\mathrm{CO}_{2}$ showed better growth rate than those grown in closed system on both media with sucrose and without sucrose. Morphologically, plantlets grown by PMS system and its modification has stronger habitus than those grown using the closed system (Figure 1). However, the same effect was also seen after adding $10 \mathrm{~g} / \mathrm{L}$ sucrose in the closed system.

$\mathrm{CO}_{2}$ addition in the system affected the leaf growth, especially when compared with closed culture with sucrose concentration of $20 \mathrm{~g} / \mathrm{L}$. However, plantlet leaves grown in PMS with an addition of $5 \mathrm{~g} / \mathrm{L}$ sucrose were longer when compared with all treatments. In addition to the leaf length, the leaf number in the plantlets grown on PMS was also increased. It also happened to the leaves on the plantlets grown in the closed system with an addition of $20 \mathrm{~g} / \mathrm{L}$ sucrose (Figure $2 \mathrm{a}$ and $2 b)$. This also shows that the function of photosynthesis would be more optimum if the size and quantity of leaves increased.

The number of roots in the plantlets grown in PMS increased. Sucrose addition on PMS (starts from 5-10 g/L) would increase the average of plantlet roots quantity up to 5.7 times. Root growth was also shown by the root elongation. Plantlets grown in PMS with the addition of 5-20 g/L sucrose have a better average of root length compared to the closed system (Figure $2 \mathrm{c}$ and $2 \mathrm{~d}$ ). This shows that the function of nutrient absorption by the root will be more effective using PMS.

\section{Leaf anatomy}

In addition to the length and number of leaves, leaf thickness and stomata density was also observed. The results showed that the leaves of plantlets in the treatment of a closed system, in general, were thicker compared to PMS. The addition of sugar to PMS had a tendency to increase leaf thickness for more than $50 \%$ compared to PMS. Leaves appeared to become increasingly thicker within a closed system with the addition of $20 \mathrm{~g} / \mathrm{L}$ of sucrose (Table 2). It suggests that
Table 2. The thickness of G. scriptum plantlet crosssection incision on various treatments.

\begin{tabular}{llr}
\hline No & Treatment & $\begin{array}{c}\text { Leaf thickness } \\
(\mu \mathrm{m})\end{array}$ \\
\hline 1 & Closed bottle, 0 g/l sucrose & 162.024 \\
2 & Closed bottle, $5 \mathrm{~g} / 1$ sucrose & 156.663 \\
3 & Closed bottle, $10 \mathrm{~g} / 1$ sucrose & 165.261 \\
4 & Closed bottle, 20 g/1 sucrose & 260.424 \\
5 & Sucrose PMS bottle 0 g/1 sucrose & 67.083 \\
6 & Sucrose PMS bottle $5 \mathrm{~g} / 1$ sucrose & 135.404 \\
7 & Sucrose PMS bottle $10 \mathrm{~g} / 1$ sucrose & 92.0291 \\
8 & Sucrose PMS bottle $20 \mathrm{~g} / 1$ sucrose & 117.443 \\
\hline
\end{tabular}

closed system can lead the plantlet leaf thickness increased due to the high water content in the culture system. This causes the cells to undergo expansion. However, the factors that led to leaf cell division has not been observed in this study.

In ex vitro, G. scriptum, stomata could be found on both sides of the leaf, which is both the adaxial and abaxial side. It is evident in Figure 3 that the quantity of stomata on the adaxial section of the leaf is much larger and denser compared to its abaxial section. Stomata open around 7:00 AM in the morning and close at night. It indicates that $\mathrm{CO}_{2}$ absorption occurs from morning to evening. However, the precise time on which stomata closes on G. scriptum has not been investigated in this study.

The number of stomata in plantlet leaves per $4 \mathrm{~mm} 2$ increased in a closed system. The stomata would then decline in PMS. In a closed system with high levels of sucrose

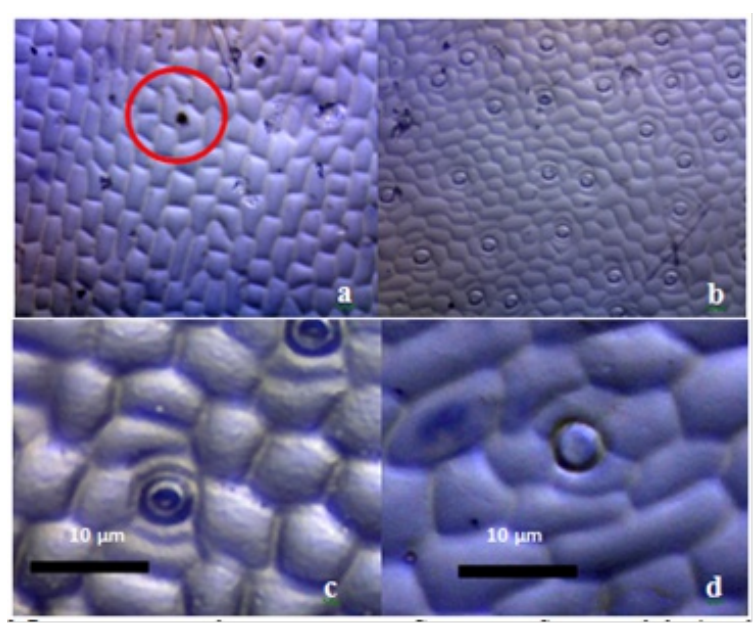

Figure 3. Stomata cross-section on ex vitro G. scriptum leaves: a) adaxial stomata (red circle); b) abaxial stomata; c) abaxial stomata in the morning at $07.00 ; d$ ) abaxial stomata at night at 19.00 . 


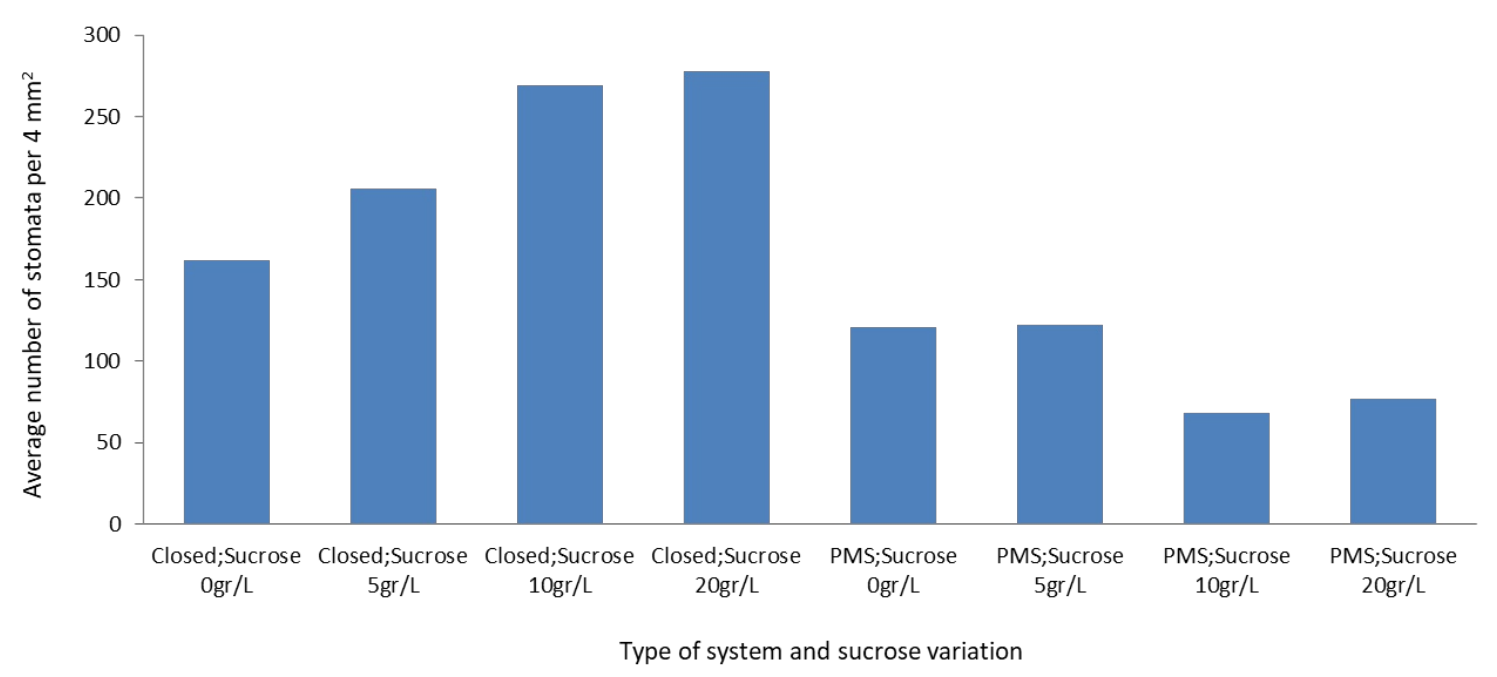

Figure 4. Comparison of the number of stomata per $4 \mathrm{~mm}^{2}$ area in G. scriptum abaxial plantlets leaves within a closed system and PMS, with sucrose variations in VW mediums (for 8 weeks).

$(20 \mathrm{~g} / \mathrm{L})$, the number of stomata had increased to almost $30 \%$, or 115 stomata per $4 \mathrm{~mm}^{2}$. The addition of $\mathrm{CO}_{2}$ and $10 \mathrm{~g} / \mathrm{L}$ sucrose lowered the number of stomata to 94.33 stomata per $4 \mathrm{~mm}^{2}$, or as much as $40 \%$ less compared with the closed systems without the addition of sucrose (Figure 4). This may indicate that the presence of $\mathrm{CO}_{2}$ in the PMS can reduce the number of stomata. It is suspected that there is a connection between $\mathrm{CO}_{2}$ and the number of stomata per unit area.

\section{Chlorophyll level}

The quantity of chlorophyll related to the level of photosynthetic activity. Increased chlorophyll levels mean increased photosynthesis activity, and thus can be used as an indicator of growth and effectiveness of $\mathrm{CO}_{2}$ binding. The total chlorophyll quantity, or chlorophyll $\mathrm{a}$ and $\mathrm{b}$ in PMS with additional $10 \mathrm{~g} / \mathrm{L}$ sucrose, showed the highest results. Without the addition of sucrose, plantlets grown on PMS showed an increase in the quantity of total chlorophyll compared to plantlets in a closed system without the addition of sucrose, which quantified to almost 25\% (Figure 5). This shows that there is a connection between chlorophyll content and addition of $\mathrm{CO}_{2}$.

Cultured in vitro orchids have shown lower acclimation success rate. This is due to differences between the environmental conditions (ex vitro) at the time of acclimatization and conditions when the plantlets were cultured in vitro. Such differences include the level of moisture, nutrient supply, temperature, light intensity, and carbon dioxide for photosynthesis. In this culture, aseptic conditions must be maintained in order to prevent contamination by bacteria or fungi, through sterile conditions and closed systems. However, this can lead to a shortage of carbon dioxide resulting in reduced effective autotrophic function of the plantlets.

PMS is expected to supply plantlets with carbon dioxide, which in turn will accustom these plantlets to start photosynthesising optimally during in vitro because they are supported by an adequate supply of carbon dioxide. Carbon dioxide acts as a raw material in photosynthesis (high carbon dioxide levels support plant growth). In this system, the plantlets were grown on a medium without sucrose. The process aims to prioritize the $\mathrm{CO}_{2}$ consumption as a carbon source for plantlet photosynthesis rather than sucrose. This will result in optimal photosynthesis during acclimatization while increasing the survival of plantlets in ex vitro conditions.

In addition to the increase of carbon dioxide from the air, which flows through the gooseneck pipe, the plantlets in VW medium were also given various sucrose 


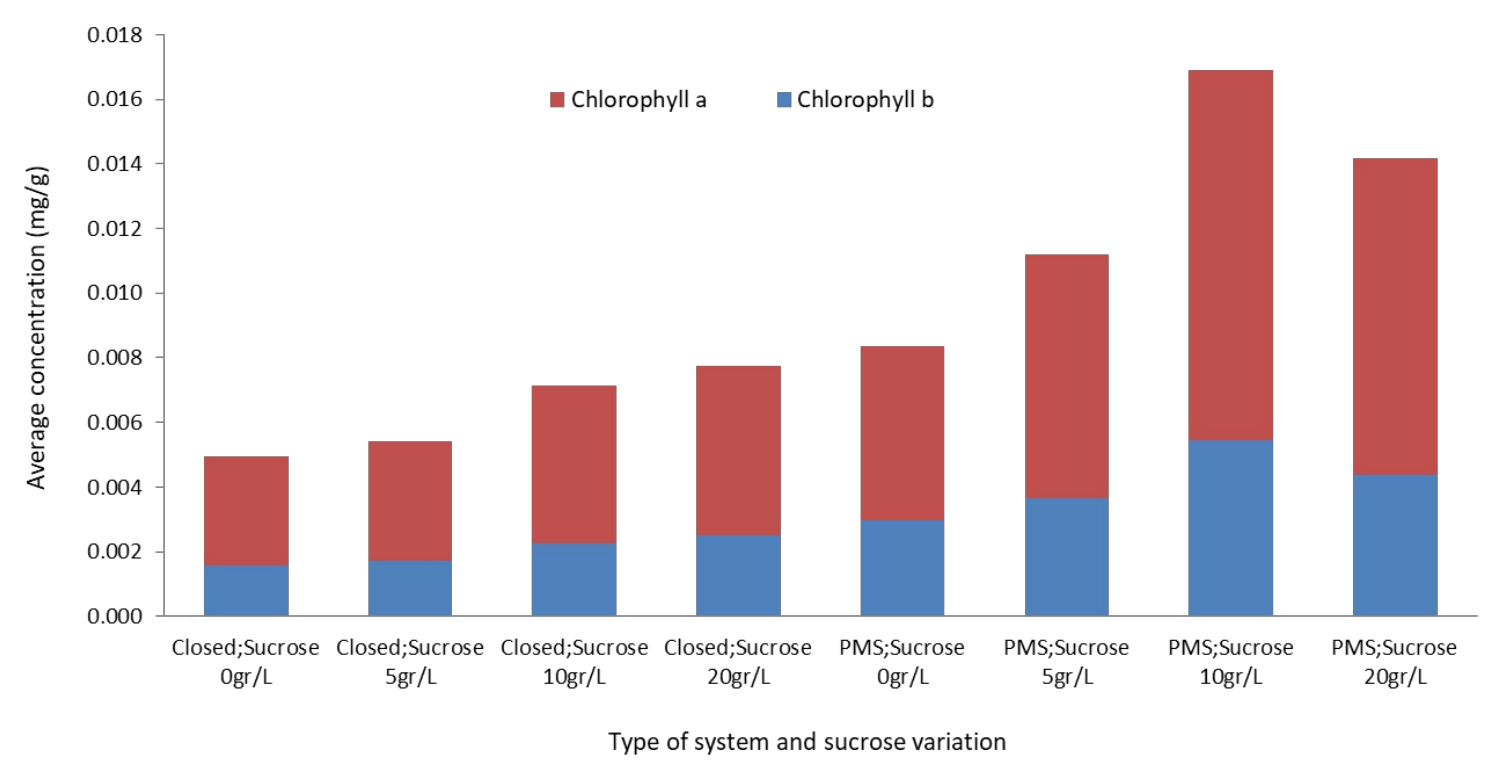

Figure 5. Average concentration of chlorophyll a, b and the total (mg/g) in G. scriptum plantlets within a closed systems and PMS, with sucrose variations in VW mediums (for 8 weeks).

treatments. The plantlets ability to photosynthesize in in vitro conditions also decreased, thus requiring more exogenic carbon for growth, which could be obtained from sugar or sucrose (Hew and Yong, 2004). This led to the need to understand the correlation between carbon dioxide levels and sucrose quantity, both of which were nutrients needed by the plantlets. In general, 20-30 g/ L of sucrose was added to every liter of the medium. With the addition of more carbon dioxide, it was hoped that the amount of nutrient given to each growth medium could be decreased to increase the plantlets autotrophic attribute. The increase in carbon dioxide levels should be proportional to the increase in the plantlets growth parameter. The study measured the growth parameters of G. scriptum orchids, which were leaf quantity, leaf length, root quantity, and root length.

A large number of leaves in the PMS treatment with the addition of $20 \mathrm{~g} / \mathrm{L}$ sucrose showed that there was a large sugar sink capacity within G. scriptum plantlets. According to Campbell et al. (2004), plants have organs that function as sugar sink and sugar source. Organs that function as sugar sinks are roots, tubers, stems, fruits, and leaves in their development phases (Campbell et al. 2004). Therefore, as plantlets receive a large sugar supply, it can be then stored in the stem.
It is similar to fully developed leaves and it indicates that sugar levels can increase the number of leaves in the plantlets.

The roots are essential during acclimatization. For this reason, during acclimatisation plantlets that are chosen should have strong roots in order to adapt to ex vitro environments and can quickly absorb water and other nutrients content in the acclimatization medium. The existence of long and abundant roots can increase a plant ability to absorb nutrients. This is especially true for epiphytic plants like the G. scriptum.

Photosynthesis process in plants is not only affected by light, water, carbon dioxide levels and other factors but it is also greatly influenced by the chlorophyll within the plants themselves (Sasmitamihardja and Siregar 1997). Chlorophyll is a green plant pigment and is located in the chloroplasts. The ratio of chlorophyll a and chlorophyll b in higher plants is 3:1 (Suprapti, 2005). This study measured the levels of chlorophyll a, chlorophyll b, and the total chlorophyll amount within plantlets in each individual treatments. High chlorophyll levels indicate that the plants are actively photosynthesizing and can also be applied as a growth indicator.

This study also observed G. scriptum anatomically by examining leaf stomata and leaf thickness by measuring its cross-section. Orchid leaves are generally divided into two 
types, thin and succulent (Hew and Yong, 2004). Leaf thickness is associated with photosynthetic activity. Thin-leaved orchids generally have type $\mathrm{C} 3$ photosynthesis, while the thick-leaved variant have CAM (Crassulacean Acid Metabolism). Apart from the thickness of the leaves, photosynthesis types can also be seen from the time of stomatal opening. C3-type plants' stomata will open at noon, while CAM plants' opens at night. This is a form of environmental adaptation to temperature and water availability (Zots and Tyree, 1996). CAM plants are usually plants that can adapt in dry places. Crop yielded from in vitro culture generally have thick leaves. Differences in the thickness of the leaves can be affected by the division of parenchyma cells in the mesophyll. It can also be caused by parenchyma cells increasing in size on mesophyll due to high moisture condition. Moisture or atmospheric water content is an important factor that affects the success rate of acclimatization. In vitro culture plantlets commonly have thick leaves because the plantlets grew on a medium with high humidity. This is due to the extreme environment switch, which resulted low acclimatisation success rate. Thinner leaves, on the other hand, are assumed to be more adaptable in environments with low humidity. PMS treatment during the in vitro culture process was known to have lower air moisture around plantlets due to the increased air circulation inside the culture bottle that flows through the gooseneck pipe opening.

Stomata were found on both the adaxial and abaxial sides of the leaf, making the leaf belong to amfistomatic. However, it is evident in Figure $3 b$ that the number of stomata on the abaxial leaves is much larger and denser than those of abaxial leaves (Figure 3a). Figure $3 c$ and $3 d$ shows that G. scriptum leaf stomata opens in the morning at around 07.00 and closes at 19.00 in the evening. This proved that G. scriptum has type C3 photosynthesis because the stomata open in the morning, thus carbon dioxide fixation took place in the morning.

Stomata has become an important object of observation because the majority of moisture within a plant will exit through the structure (Zots and Tyree, 1996). Stomata is also a highly adaptive structure. Desert plants have a lower stomata density compared to the plants that grow in wetter environments. Campbell et al. (2004) stated stomata density is flexible and changes accordingly depending on the treatment given. Addition of light intensity and low carbon dioxide levels can increase stomata density (Campbell et al., 2004).

\section{Conclusions}

The use of PMS or an open system with additional $\mathrm{CO}_{2}$ from the air and sugar-free medium can increase the growth of G. scriptum plantlets. PMS provides better results in terms of morphology, anatomy, and physiology, increases leaf and root growth, lower stomata count, thicker leaves, and higher chlorophyll levels.

\section{Acknowledgments}

The researchers are thankful for the support from Universitas Gadjah Mada Research Directorate through the Progran Peningkatan Kapasitas Peneliti Dosen Muda dengan Sumber Dana Bantuan Pendanaan Perguruan Tinggi Negeri Badan Hukum Direktorat Penelitian (Capacity Enhancement for Young Lecturer Researchers Funded through Financial Assistance for Autonomous Public Universities from the Research Directorate) number: 1590/UN1-P.IIILT/ DIT-LIT/ 2016 dated April 28, 2016.

\section{References}

Arditti, J. (2008) Micropropagation of Orchid. $2^{\text {nd }}$ edition vol. 1. Oxford UK: Blackwell Publishing.

Campbell, N.A., Reece, J.B., and Mitchell, L.G. (2004) Biologi. $5^{\text {th }}$ edition vol. 1. Jakarta: Erlangga. pp. 302-310.

Haney, R., Brinton, W., and Evans, E. 2008. Soil $\mathrm{CO}_{2}$ respiration: comparison of chemical titration, $\mathrm{CO}_{2}$ IRGA analysis and the Solvita gel system. Renewable Agric. Food Syst., 23(2), 171-176. doi: 10.1017/S174217050800224X

Hani, M.R. 2015. Pengaruh penyemprotan kitosan pada aklimatisasi planlet anggrek macan (Grammatophyllum 
scriptum). Jurusan Biologi Fakultas MIPA UNS. Surakarta.

Irawati (2001) Dendrobium capra J.J. Sm. In: Mogea, J.P., Gandawijdjaja, D., Wiriadinata, H., Nasution, R.E., and Irawati (eds.). Tumbuhan Langka Indonesia. Bogor: Puslitbio LIPI.

Rosdiana. 2010. Pertumbuhan anggrek bulan (Phalaenopsis amboinensis) endemik Sulawesi, pada beberapa jenis dan konsentrasi zat pengatur tumbuh secara in vitro. Jurnal Agrisistem, 6(2), 88-96.

Sasmitamihardja, D dan Siregar, A. (1997) Fisiologi tumbuhan. Bandung: Jurusan Biologi FMIPA-ITB. Proyek Pendidikan Tenaga Akademik Direktorat Jenderal Pendidikan dan Kebudayaan.

Suprapti, E. (2005) Kadar klorofil dan karotenoid daun kentang (Solanum tuberosum $\mathrm{L}$ ) yang ditanam pada jarak lokasi penanaman berbeda dari sumber sulfur kawah Sikidang Dieng. Bachelor thesis. Semarang: Universitas Diponegoro.

Soeryowinoto, M. (1987) Mengenal anggrek alam Indonesia. Jakarta: PT Penebar Swadaya.

Teixera da Silva, J.A., Giang, D.D.T, and Michia, T. 2005. In vitro acclimatization of banana and Cymbidium. Int. J. Bot., 1(1), 41-49. doi:10.3923/ijb.2005.41.49.

Torres, K.C. (1989) Tissue culture techniques for horticultural crops. New York: Van Nostrand Reinhold.

Xiao, Y., and Kozai, T. 2006. In vitro multiplication of statice planlets using sugar-free media. Sci. Holtic., 109, 71-77.

Yulia, N.D., and Ruseani, N.S. 2008. Studi habitat dan inventarisasi Dendrobium capra J.J. Smith di Kabupaten Madiun dan Bojonegoro. Biodiversitas, 9(3), 190-193.

Zots, G., and Tyree, M.T. 1996. Water stress in the epiphytic orchid, Dimerandra emarginata (G. Meyer) Hoehne. Oecologia, 107, 151-159. 